\title{
Financial Support of Physical Culture and Sports Institutions in Russia
}

\author{
Sabitova N.M. \\ Institute of Management, Economics and Finance \\ Kazan Federal University \\ Kazan, Russia \\ sabitovanm@mail.ru
}

\author{
Shavaleeva Ch.M. \\ Federal Scientific Center of Physical Culture and Sports \\ Moscow, Russia \\ Institute of Management, Economics and Finance \\ Kazan Federal University \\ Kazan, Russia \\ chulpan212@mail.ru
}

\author{
Bolonina E.V. \\ Institute of Management, Economics and Finance \\ Kazan Federal University \\ Kazan, Russia \\ alenyshka1983@mail.ru
}

\begin{abstract}
The article considers the existing system of state and municipal financing of physical culture and sports in the Russian Federation as one of the important branches of the social sphere. Financing of physical culture and sports is carried out through the budget system of the Russian Federation, with the main share of funding coming from regional and local budgets. In recent years, expenditures on financing physical culture and sports have been growing faster than the total expenditures of the consolidated budget of the Russian Federation. In Russia there is a wide network of Federal, regional and municipal organizations that receive various subsidies from the budget system of the Russian Federation. These include budgetary and Autonomous institutions, unitary enterprises. The article analyzes the financial support of budgetary institutions subordinated to the Russian Federation Ministry of sports. These institutions carry out the state task to provide services in the field of physical culture and sports. It is revealed that the main share of all subsidies allocated for the financing of physical culture and sports are subsidies for the financial support of the state task. They are calculated by sports on the basis of normative costs for the provision of state (municipal) services in the field of physical culture and sports. They are different for organizations of Federal, regional and local subordination. The analysis showed that half of the expenditure falls on the sport of higher achievements, which is understandable, given the importance and necessity of state support for the development of this area.
\end{abstract}

Keywords-subjects of financing; sources of financing; budgets of the budget system of the Russian Federation; incomes of institutions; efficiency of expenses.

\section{INTRODUCTION}

Physical culture and sports are one of the important branches of the social sphere, which is supported by the state and financed from the budgets of the Russian Federation budget system. In Russia, there is a wide network of state and municipal organizations of physical culture and sports, which can be both commercial and non-commercial, created in various organizational and legal forms. These organizations are subordinated to the Russian Federation Ministry of sports, ministries of sports of the Russian Federation subjects and committees (departments) of physical culture and sports in municipalities. These organizations are financed from the budgets of the Russian Federation budget system. Expenses of the Russian Federation budgetary system budgets connected with the financing of actual physical culture, mass sport development, high performance sport, applied research in the field of physical culture and sport and other issues in the field of physical culture and sports. Financing of physical culture and sports through the budget system of the Russian Federation according to official data of the Russia Federal Treasury published on their website is growing, in 2016 262,252. 5 million. in 2018-331 448,9 million rubles, that is, there is an increase in costs by $126,4 \%$. At the same time, the expenses of the Russian Federation consolidated budget increased for this period only by $109.5 \%$. Thus, it can be noted that the costs of physical education and sports are growing more significantly than all total costs. This is a good trend for this social sector. If we consider the share of spending on physical culture and sports in the consolidated budget of the 
Russian Federation, it was $0.83 \%$ in 2016 , $0.97 \%$ in 2018 , that is, there is also a tendency of small growth.

\section{LITERATURE REVIEW}

Given the importance of the physical culture and sport development, its impact on the health and economy of all countries, this issue is given much attention both in the Russian Federation and in other countries. Questions of the management research current state in the field of sports management are considered in the article Dowling, Mathew; Leopkey, Becca; Smith, Lee (5), structural business model for sports organizations and the impact of direct public investment in sports infrastructure in the article Dilys, Mantas; Gargasas, Audrius (1). Economic aspects of sports organizations relations with municipalities and sports federations are considered in the article Pavlik, Marek (11). The problems of organization of financing of physical culture and sports by countries are considered in the works. Dumancic, Darko; Siric, Zeljko [3], Nemec, Juraj; Nemec, Miroslav; Pavlik, Marek (10); Skoric, Sanela; Hodak, Zlatko(15). Dittrichova, Jaroslav (2), the use of alternative sources of sports financing in different countries, Pavlik, Marek are devoted to the study of the public ratio and sports private financing; Hruza, Filip (12). Among the Russian authors, the study of the financing of physical culture and sports is devoted to the work of Kurochkin V. V. (9), the problems of expenditures efficiency on physical culture and sports are devoted to the work of Doev V.K. (4), Kireeva I. R. (6,7,8) Pinskaya M. R. (13), Sabitova N. M. (14), etc.

\section{RESEARCH METHODOLOGY}

State and municipal organizations of physical culture and sports in the Russian Federation are created in the form of budgetary and Autonomous institutions and unitary enterprises. There is a feature of the organizations of physical culture and sports fixing on levels of the Russian Federation budgetary system. Distribution of expenditure obligations on levels of budgetary system of the Russian Federation is carried out according to the Federal law of 04.12.2007 No. 329-FZ "About physical culture and sports in the Russian Federation". In each subject of the Russian Federation also there are the organizations subordinated to the corresponding ministries of the Russian Federation sports subjects, their number depends on a number of factors, including population size. So in the Republic of Tatarstan institutions subordinated to the Ministry of sports of RT 19, in the Samara region 14, in the Republic of Bashkortostan - 15. At the municipal level, the number of organizations also differs both in the subjects of the Russian Federation and within the subjects of the Russian Federation by types of municipalities. For example, in the municipal formation Kazan (urban district) - 42, the municipal formation Naberezhnye Chelny (city district) - 16 in Almetyevsk municipal district of the Republic of Tatarstan - 7. These are mainly children's sports schools. But these are organizations in large municipalities of the Republic of Tatarstan. In other municipalities the organizations financed from budgets of municipalities can be absent. At the level of the Russian Federation subjects and municipalities, these are mainly children's sports schools, Olympic reserve schools, sports complexes and others.

Currently, out of 39 organizations subordinated to the Russian Federation Ministry of sports, 35 are budgetary institutions, 3 organizations are unitary and 1 is an autonomous institution. Among the budgetary institutions there are training centers and sports training centers (10 institutions), academies (6 institutions), universities (5 institutions), institutes (3 institutions), schools/colleges (3 institutions), schools/technical schools (8 institutions). The peculiarity of budgetary institutions is that they belong to nonprofit organizations created by the Russian Federation, a subject of the Russian Federation or a municipal entity to perform works, provide services in order to ensure the implementation of the relevant powers, including in the field of physical culture and sports. Their activity is carried out on the basis of the state (municipal) task.

For research of physical culture and sports establishments financial support questions by us as object of research budgetary establishments subordinated to the Russian Federation Ministry of sports were taken. These institutions are financed both from budgetary subsidies and from extrabudgetary sources, including income from the provision of services (performance of works) on a paid basis and from other income-generating activities.

\section{RESULTS}

The study of the expenditures structure on physical culture and sports in the budgets of the Russian Federation budget system for 2018 shows that the main share of all expenditures falls on sports of higher achievements $50.2 \%$, physical culture itself accounts for $26.1 \%$, mass sports $17.2 \%$, applied scientific research in the field of physical culture and sports make up $0.1 \%$, other issues in the field of physical culture and sports $6.4 \%$ (Fig. 1 ).

Analysis of budgets costs shows that the share of the Federal budget is only $19.3 \%$, the remaining costs are at the expense of the Russian Federation subjects budgets and local budgets. At the same time, only $100 \%$ of the expenditures for applied scientific research are carried out at the expense of the Federal budget. Sports of the highest achievements on $29,9 \%$, mass sports of $14,8 \%$ are financed from the Federal budget. The share of the Federal budget in other expenditures is insignificant (table I).

The analysis of physical culture and sports budget institutions financing sources structure under the Ministry of sports of Russia for 2016-2018 shows that the share of budget financing which is carried out in the form of budget subsidy across the three years extra-budgetary funds, while in 2017 this share was somewhat lower. But in total there is an increase in subsidies. There has also been a significant increase in extrabudgetary funding, especially in 2017, which 
is clearly related to the preparations for the world Cup events (table 2).

TABLE I. EXPENDITURES OF THE RUSSIAN FEDERATION CONSOLIDATED BUDGET ON PHYSICAL CULTURE AND SPORTS FOR 2018

\begin{tabular}{|l|c|l|l|}
\hline & $\begin{array}{c}\text { consolidated } \\
\text { budget of the } \\
\text { Russian } \\
\text { Federation, (in } \\
\text { millions of } \\
\text { rubles) }\end{array}$ & \multicolumn{1}{|c|}{$\begin{array}{c}\text { among them: } \\
\text { Federal budget (in } \\
\text { millions of rubles) } \\
\text { UD weight (W \%) }\end{array}$} \\
\hline Physical culture and sports total & 331448,9 & 64019,6 & 19,3 \\
\hline Physical culture & 86552,7 & 4143,5 & 4,8 \\
\hline Mass sports & 57085,0 & 8434,4 & 14,8 \\
\hline Sport of the highest achievements & 166483,5 & 49749,6 & 29,9 \\
\hline $\begin{array}{l}\text { Applied scientific research in the } \\
\text { field of physical culture and } \\
\text { sports }\end{array}$ & 253,1 & 253,1 & 100 \\
\hline $\begin{array}{l}\text { Other issues in the field of } \\
\text { physical culture and sports }\end{array}$ & 21074,6 & 1439,0 & 6,8 \\
\hline
\end{tabular}

TABLE II. SOURCES OF PHYSICAL CULTURE AND SPORTS FINANCING UNDER OF THE RUSSIAN FEDERATION MINISTRY OF SPORTS

\begin{tabular}{|c|c|c|c|c|c|c|}
\hline \multirow{2}{*}{ Indicator } & \multicolumn{2}{|c|}{2016} & \multicolumn{2}{c|}{2017} & \multicolumn{2}{c|}{2018} \\
\cline { 2 - 7 } & $\begin{array}{c}\text { Amount } \\
\text { (in } \\
\text { millions, } \\
\text { RUB.) }\end{array}$ & $\begin{array}{c}\text { specific } \\
\text { weight in } \\
\%\end{array}$ & $\begin{array}{c}\text { Amount } \\
\text { (in } \\
\text { millions, } \\
\text { RUB.) }\end{array}$ & $\begin{array}{c}\text { specific } \\
\text { weight in } \\
\%\end{array}$ & $\begin{array}{c}\text { Amount } \\
\text { (in } \\
\text { millions, } \\
\text { RUB.) }\end{array}$ & $\begin{array}{c}\text { specific } \\
\text { weight in } \\
\%\end{array}$ \\
\hline Revenues total & 20159,3 & 100 & 32346,6 & 100 & 26944,1 & 100 \\
\hline among them: & 17266,2 & 85,6 & 19537 & 60,4 & 21165,5 & 78,6 \\
\hline budget subsidies & 1726,6 & 39,6 & 5778,6 & 21,4 \\
\hline $\begin{array}{c}\text { extrabudgetary } \\
\text { funds and other } \\
\text { income }\end{array}$ & 2893,1 & 14,4 & 12809,6 & 30 & \\
\hline
\end{tabular}

Budget subsidies are provided to institutions of physical culture and sports in the form of subsidies for financial support of the state task, as well as other targeted subsidies, including for capital investments. Extra-budgetary sources of income for the analyzed institutions were attracted in the form of income from property, including rent, income from the provision of paid services and other revenues.

If we analyze the structure of subsidies, we see that budget institutions for 2016-2018 received targeted subsidies for financial support of the state task. At the same time, there is an increase in them, mainly due to other targeted subsidies. The share of subsidies for financial support of the state task performance on years is respectively $87,6 \%, 79,8 \%, 76,7 \%$ (table 3).

Budget subsidies of the state task financial support for subordinate institutions of the Russian Federation Ministry of sports for various sports are calculated on the basis of normative costs for the provision of state (municipal) services in the field of physical culture and sports. In 2019, new requirements were established to determine the regulatory costs for the provision of state (municipal) services in the field of physical culture and sports. It will be effective from 2020 . Institutions of physical culture and sports for receiving subsidies for financial support of the state task performance make plans of financial and economic activity on the basis of these requirements.

TABLE III. THE STRUCTURE OF THE SUBSIDIES PROVIDED BY INSTITUTIONS OF PHYSICAL CULTURE AND SPORTS UNDER THE MINISTRY OF SPORTS OF THE RUSSIAN FEDERATION IN 2016-2018

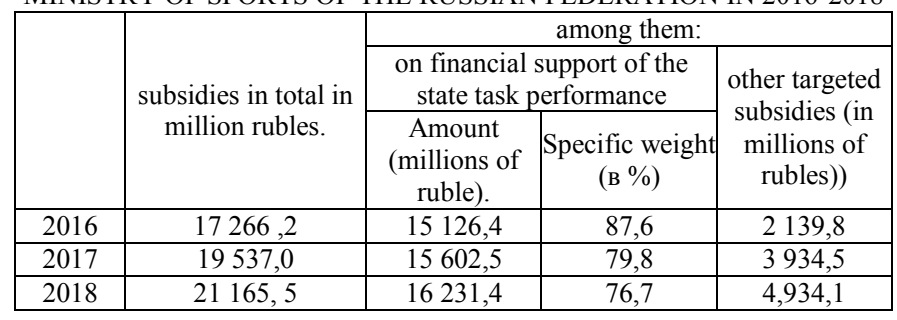

\section{DISCUSSION}

The research showed that in general in the Russian Federation there is an increase in the expenditure of the budget system on physical culture and sports. At the same time, the share of expenditures on financing of physical culture and sports is less than $1 \%$, which, in our opinion, is not enough. The main share of expenditures falls on regional and local budgets in almost all areas, this is the sport of the highest achievements, and actually physical culture, mass sports. A more detailed analysis of the Russian Federation consolidated budget expenditures composition and structure on physical culture and sports showed that half of the expenditures fall on sports of higher achievements, which is understandable, given the importance and need for state support for the development of this area. But this direction should be financed not at the expense mass sports development to ensure the growth of the citizens proportion involved in sports.

The analysis of the budgetary institutions financial support subordinated the Russian Federation Ministry of sports showed that their incomes are formed at the expense of budgetary subsidies, and also off-budget sources. There is an increase in budget subsidies, the main share is provided for financial support of the state task. The analysis showed the stability of these revenues, and therefore the state task. Extrabudgetary sources of income for the analyzed institutions were attracted in the form of income from property, including rent, as well as income from the provision of paid services and other revenues. There is also an increase in these revenues. It is important not only the dynamics of physical culture and sports budget financing indicators, but also their effectiveness. It can be noted, for example, the increase in the proportion of citizens systematically engaged in sports. According to the Russian Federation Ministry of sports, it was $31.7 \%$ in 2015, $39.8 \%$ in 2018 , which can certainly be considered a positive trend [18]. 


\section{CONCLUSION}

Physical culture and sport is an important social sphere that testifies to the health and well-being of citizens of any country. In Russia, the system of state and municipal budget financing of physical culture and sports is implemented through a wide network of budgetary and autonomous institutions, as well as unitary enterprises through the budgets of the Russian Federation budget system. The need to increase these costs is obvious, but the focus should not be only on high-performance sports

\section{References}

[1] Dilys, Mantas, Gargasas Audrius. Structural Business Model Based on Cooperation between Sports Organizations and Sponsors. Inzinerine ekonomika-engineering economics. 2014, vol. 25, 1, pp. 94-102.

[2] Dittrichova Jaroslava. Regional development and sport financing. International Scientific Conference on Hradec Economic Days. Economic Development and Management Region Hradec. 2013.

[3] Kralove. Czech republic. International conference: Hradec economic days 2013 - economic development and management of regions, RT. 2013, III, pp. 42-46.

[4] Dumancic Darko, Siric Zeljko. Sport in osijek - yesterday, today, tomorrow. 1st International Scientific Symposium Economy of Eastern Croatia - Yesterday, Today, Tomorrow. 2012, pp. 280-288.

[5] Doev V.K. Social and economic efficiency of physical culture and sports. Economic analysis: theory and practice. 2012, 9(264), pp. 5458.

[6] Dowling Mathew, Leopkey Becca, Smith Lee. Governance in Sport: A Scoping Review. Journal of sport management. 2018, vol. 32, 5, pp. 438-451.

[7] Kireeva I.R. Financial aspects of staging international sports events. Theory and practice of physical culture. 2015 , vol. 4, pp. $52-55$

[8] Kireeva I.R. Evaluation of the efficiency of the region's expenditures on physical culture and sports: the experience of the Republic of Tatarstan. Economic and legal Issues. 2013, 2, pp. 127-138.

[9] Kireeva I.R. On the issue of efficiency and effectiveness of budget financing of physical culture and sports. Economic Sciences. 2013, 2(99), pp. 144-146.

[10] [9] Kurochkin V. V. Financing of physical culture and sport in Russia / Interactive science. 2016.No. 10.Pp. 137-140 [10] Nemec, Juraj; Nemec, Miroslav; Pavlik, Marek Public Financing of Sports in the Czech Republic and Slovakia // 4th International Conference on Education and Sports Education (ESE). Hong Kong, PEOPLES R CHINA: APR 11-12, 2013

[11] Pavlik Marek. Sport Clubs and Economic Aspects of their Relations with Municipalities and Sport Federations. $17^{\text {th }}$ International Conference on Current Trends in Public Sector Research. 2013.

[12] Pavlik Marek, Hruza Filip. Lottery as Tool for Financing of Sport Comparison of European Countries. 2nd International Conference on Applied Social Science Research (ICASSR). 2014, vol. 104, pp. 89-92.

[13] Pinskaya M.R., Ziganshina L.A. Conceptual approaches to assessing the economic efficiency of expenditures on physical culture and sports. IEAU Bulletin. 2018, 21, pp. 22-26.

[14] Sabitova N.M. On the issue of budget efficiency. Bulletin of the Kazan state financial and economic Institute. 2005, 1, pp. 52-55.

[15] Skoric Sanela, Hodak Zlatko. The system of sports financing and management in the Republic of Croatia. Zbornik radova ekonomskog fakulteta u RIJECI-proceedings of Rijeka faculty of economics. 2011, vol. 29, 2, pp. 443-464.

[16] Official website of the Federal Treasury of Russia. URL: https://roskazna.ru/ispolnenie-byudzhetov/konsolidirovannyj-byudzhet/

[17] Official website for information on state (municipal) institutions "Electronic budget". URL: https://bus.gov.ru
[18] Official website of the Ministry of sports of the Russian Federation. URL: https://www.minsport.gov.ru/press-centre/speeches/28895/)

[19] Alexsandr S. Kuznetsov. Russian Professor's meeting. Russian Journal of Physical Education and Sport. 2019, 14(1), pp. 17-22. DOI: $10.14526 / 2070-4798-2019-14-1-18-24$

[20] Federal law No. 329-FZ of 04.12.2007 "On physical culture and sport in the Russian Federation". 